\title{
Characteristics of Coastal Saline Soil and their Management: A Review
}

\author{
C. Arulmathi and G. Porkodi* \\ ICAR-Krishi Vigyan Kendra, Cuddalore, Tamil Nadu, India \\ *Corresponding author
}

\section{A B S T R A C T}

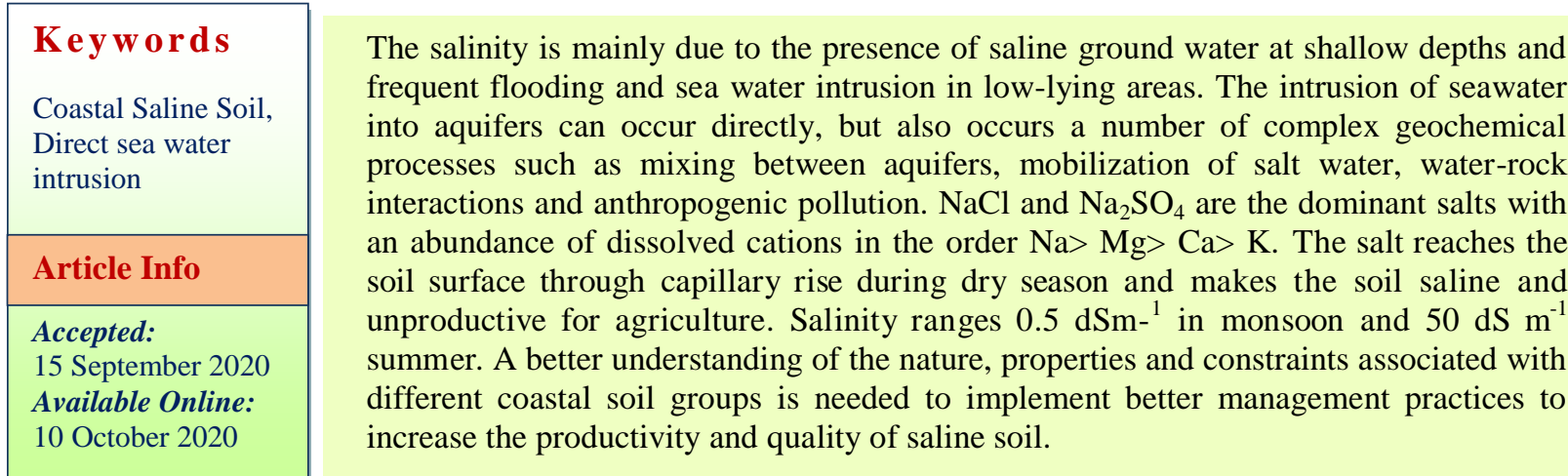

\section{Introduction}

In India, the total area under salt-affected soils is 7.3 million hectare (Mha). Low productivity of this ecosystem is attributed to the unfavorable agro-climatic conditions. Coastal soils are encountered with various abiotic stresses viz., salinity, acidity, waterlogging and sandy texture. Most of the coastal areas have problematic soils, such as saline, alkaline, acid sulphate, marshy and waterlogged soils, situated in low-lying areas, mainly along the deltas. Coastal salinity is the main factor responsible for poor yield of crops growing an area of about 3.1 million hectares.
Direct sea water intrusion, intrusion through estuaries and the upward movement of salt from shallow water table are the major causes of salinity in salt-affected soils. Ingression of salt water in fields during monsoon season and its subsequent recession during winter and summer leaves the salt residues behind, which keeps accumulating on the surface due to upward movement and evapotranspiration. A very peculiar situation of coexistence of salinity and acidity is normally observed in these soils.

Salinity causes severe constraints to crop production in these soils. Salinity causes soil structural changes and alters soil physical processes affecting water and air movement 
and available water capacity (Oster and Jaywardane 1998). This further affects the osmotic and matric potential and microbial activities (Reitz and Haynes, 2003; Sardinha et al., 2003). This ultimately reduces the rate of organic matter decomposition and release of nutrients and thereby affect the plant growth. Soil microbial community structure, their activities and enzyme activities are adversely influenced by the salinity (Reitz and Haynes 2003; Vijayakumar et al., 2013). Velayutham et al., (1999) revealed that saline soil resource and their potentials for different Agro-ecological Sub Regions (AESR) of India. It shows total 10.78 million hectare area under this ecosystem (including the islands) in India, which was the first scientific approach for delineation of the coastal soils. Extent and distribution of coastal area in India is presented in table 1 and Soil salinity classes and crop growth is presented in table 2 .

\section{Major coastal soils and their formation}

Coastal soils are rich in salts, mainly due to the presence of saline ground water table at shallow depth and frequent brackish water inundation in the low lying areas. The ground water influenced by sea and brackish water estuaries reaches the soil surface through capillary rise during dry season, evaporates from the soil leaving salts behind, finally making the soil saline and unproductive for agricultural crops. The soil salinity thus shows high temporal and spatial variation depending on the elevation, soil texture, climate (evapo-transpiration, precipitation, wind velocity, relative humidity etc.), drainage and other related factors. The saltladen sands blown by sea winds are also greatly responsible for formation of coastal salt-affected soils. Development of acid sulphate soils in coastal areas is the result of the drainage of soils that are rich in pyrites $\left(\mathrm{FeS}_{2}\right)$ which on oxidation produce sulphuric acid in presence of excess sulphate ions in soil. Pyrites accumulate in waterlogged soils that are rich in both soil organic matter (SOM) and dissolved sulphates.

\section{Characteristics of coastal saline soils and their formation}

In coastal saline soil, the salinity status widely fluctuates from ECe $0.5 \mathrm{dSm}^{-1}$ in monsoon to $50 \mathrm{dSm}^{-1}$ in summer/drymonth. Mostly $\mathrm{NaCl}$ followed by $\mathrm{Na}_{2} \mathrm{SO}_{4}$ are the dominant soluble salts, with abundance of soluble cations in the order of $\mathrm{Na}>\mathrm{Mg}>\mathrm{Ca}>\mathrm{K}$. Chloride is the predominant anion, and bicarbonate is found in traces. In India, the soils are, in general, free of sodicity except in a few pockets in the South and Westcoast. Saline soil can be classified as the soils having $\mathrm{pH}$ less than 8.5, ESP less than 15, and preponderance of chlorides and sulfates of sodium, calcium and magnesium. Properties of soils at different coastal places of the east coast is presented in table 3 .

Bandyopadhyay et al., (1987) observed that coastal saline soils are characterized by clay loam with varied presence of silt and sand. The electrical conductivity ranges from 0.5 to $9.2 \mathrm{dSm}^{-1}$ with sodium as dominating caution in the salts. Biswas et al., (1990) observed that coastal saline soils generally have highly saline shallow under groundwater table with gradual upward movement of saline water during summer months and subsequent evaporation of the water that contributes to soil salinity during dry periods. Salinity is one of the major obstacles to crop yield in deltas, estuaries and coastal fringes in the humid tropics. It is a serious impediment to growth of irrigated rice (Ponnamperuma, 1972). The salinity of the soil varies with the season. It reaches the maximum between January and May and decreases there after with the on set of monsoon (Bandyopadhyay and Bandyopadhyay, 1984). This cyclic salt accumulation and intermittent flood make 
these regions predominant in rice cultivation. Rajput and Polara (2012) reported presence of high salinity (EC 1.09 to $17.8 \mathrm{dS} \mathrm{m}^{-1}$ ) in the coastal soils of Bhavnagar district of Gujarat, however, on the contrary to results of the present investigation, they observed higher soil $\mathrm{pH}$ (neutral to alkaline i.e. 7.0 to 8.9 ). Mahajan et al., (2015), stated that, the coastal saline soils of Goa were found low, low to medium and medium to high with respect to soil available $\mathrm{N}, \mathrm{P}$ and $\mathrm{K}$, respectively. The soils were sufficient with respect to DTPAextractable micronutrients - Fe, $\mathrm{Mn}, \mathrm{Zn}$ and $\mathrm{Cu}$ and hot water soluble $\mathrm{B}$.

The main obstacle to intensification of crop production in the coastal areas is seasonally high content of salts in the root zone of the soil. The salts enter in land through rivers and channels, especially during the later part of the dry (winter) season, when the down stream flow of fresh water becomes very low. During this period, the salinity of the river water increases. The salts enter the soil by flooding with saline river water or by seepage from the rivers, and the salts become concentrated at the surface through evaporation. The saline river water may also cause an increase in salinity of the ground water and make it unsuitable for irrigation. Coastal salines oils, the problem is further complicated by inundation through back wash from sea, tidal waters, wind borne salts and underground intrusion of sea water in sub soils.

\section{Constraints in coastal saline soil}

The major constraints are as follows

More accumulation of soluble salts and alkalinity in soil,

Pre-dominance of acid sulphate soils,

Toxicity and deficiency of nutrients in soils,

Intrusion of seawater into underground aquifers,
Shallow depth to underground water table rich in salts,

Periodic inundation of soil surface by the tidal water vis-à-vis climatic disaster and their influence on soil properties,

Fines oil texture and poor in filter ability of soil in many areas,

Eutrophication, hypoxia and nutrient imbalance,

Erosion and sedimentation of soil, and

High population density (Table 4).

\section{Management approaches to improve quality and productivity of coastal soils}

Saline soils can successfully be cultivated by removing excessive soluble salts through reclamation techniques. Reclamation of saline soils depends on the local conditions, available resources and the kind of crops that can be grown during reclamation. Reclamation can be accomplished in the long run by continued irrigation and cropping, inclusion of rice in cropping system together with incorporation of large quantities of organic manure (Gupta and Abrol, 1990). Reclamation of saline soils is by reducing the soil salinity to acceptable levels. In saline soils, maintenance of crop productivity at optimum level requires consideration of salt distribution within root zones that is influenced by the water extraction pattern of the crop, the method of water application, soil profile modifications, mulching, rainwater leaching and adoption of an appropriate crop rotation involving salt tolerant cultivars (U.S. Salinity Laboratory, 1954).

\section{Leaching the soil}

Leaching is the removal of soluble salts beyond the root zone, especially in shallow rooted crops. Salinity level of salt-affected coastal soils can be reduced by leaching the soils with good quality water. This can be a better option to reclaim the cyclone affected 
soils of the coastal area also. The amount of water used for reclamation of saline soils depends on degree of soil salinity, quality of irrigation water, the soil depth to be reclaimed and the water application techniques. The process of leaching was successful in the depth of $0-10 \mathrm{~cm}$ by means of maximum leaching of salts by Mahendran (2007). In the low-lying coastal areas where water table remains shallow for most part of the year and the quality of ground water is poor, installation of sub-soil drainage system is more useful.

\section{Drainage}

Drainage is the primary method of controlling soil salinity. The system should permit a small fraction of the irrigation water (about 10 to 20 percent, the drainage or leaching fraction) to be drained and discharged out of the irrigation project. In irrigated areas where salinity is stable, the salt concentration of the drainage water is normally 5 to 10 times higher than that of the irrigation water. Salt export matches salt import and salt will not accumulate.

Table.1 Extent and distribution of coastal area in India

\begin{tabular}{|l|r|}
\hline \multicolumn{1}{|c|}{ States/Union territories } & Area $\mathbf{( k m}^{\mathbf{2}} \mathbf{)}$ \\
\hline West Bengal & 14,152 \\
\hline Orissa & 7,900 \\
\hline Andhra Pradesh & 35,500 \\
\hline Tamil Nadu & 7,424 \\
\hline Kerala & 7,719 \\
\hline Karnataka & 7,424 \\
\hline Maharashtra & 10,000 \\
\hline Goa & 220 \\
\hline Gujarat & 17,465 \\
\hline Lakshadweep & 26 \\
\hline Pondicherry and Karaikal & 3 \\
\hline \multicolumn{1}{|c|}{ Total } & $\mathbf{1 , 0 7 , 8 3 3}$ \\
\hline
\end{tabular}

Velayutham et al., (1998)

Table.2 Soil salinity classes and crop growth

\begin{tabular}{|l|c|l|}
\hline \multicolumn{1}{|c|}{ Soil Salinity Class } & \multicolumn{1}{|c|}{$\begin{array}{c}\text { Conductivity of the } \\
\text { Saturation Extract } \mathbf{( d S / m )}\end{array}$} & \multicolumn{1}{|c|}{ Effect on Crop Plants } \\
\hline Non saline & $0-2$ & Salinity effects negligible \\
\hline Slightly saline & $2-4$ & $\begin{array}{l}\text { Yields of sensitive crops may be } \\
\text { restricted }\end{array}$ \\
\hline Moderately saline & $4-8$ & $\begin{array}{l}\text { Yields of many crops are } \\
\text { restricted }\end{array}$ \\
\hline Strongly saline & $8-16$ & $\begin{array}{l}\text { Only tolerant crops yield } \\
\text { satisfactorily } \\
\text { Only a few very tolerant crops } \\
\text { yield satisfactorily }\end{array}$ \\
\hline Very strongly saline & $>16$ & \\
\hline
\end{tabular}


Table.3 Properties of soils at different coastal places of the east coast

\begin{tabular}{|c|c|c|c|c|}
\hline State/U.T. & Soil texture & pH & $\mathrm{EC}\left(\mathrm{dS} \mathrm{m}^{-1}\right)$ & Dominant salt \\
\hline West Bengal & Silty clay-Silty clay loam & $3.5-7.0$ & $4.0-35$ & $\mathrm{NaCl}, \mathrm{Na}_{2} \mathrm{SO}_{4}$ \\
\hline Orissa & Clay loam-Clay & $5.0-7.5$ & $2.0-50$ & $\mathrm{NaCl}$ \\
\hline Andhra Pradesh & Sandy loam-Clay loam & $6.0-8.8$ & $0.5-17$ & $\mathrm{NaCl}, \mathrm{Na}_{2} \mathrm{SO}_{4}$ \\
\hline Pondicherry & Sandy loam-Loam & $6.6-8.5$ & $1.0-50$ & $\mathrm{NaCl}, \mathrm{Na}_{2} \mathrm{SO}_{4}$ \\
\hline Tamil Nadu & Sandy loam-Loam & $6.0-8.2$ & $2.0-10$ & $\mathrm{NaCl}, \mathrm{Na}_{2} \mathrm{SO}_{4}$ \\
\hline $\begin{array}{l}\text { Andaman \& } \\
\text { Nicobar Islands }\end{array}$ & Loam-Sandy loam & $3.0-7.0$ & $4.0-25$ & $\mathrm{NaCl}, \mathrm{Na}_{2} \mathrm{SO}_{4}$ \\
\hline
\end{tabular}

Bandyopadhyay (1994)

Table.4 Saline tolerant varieties

\begin{tabular}{|l|l|}
\hline \multicolumn{1}{|c|}{ Crop } & \multicolumn{1}{c|}{ Variety } \\
\hline Rice & $\begin{array}{l}\text { Saline Soil: CSR-49, CSR 36, CSR 30 (basmati type), CSR 27, CSR 23, } \\
\text { CSR 13 and CSR 10. } \\
\text { Coastal saline soil: Butnath (CSRC(S)5-2-2-5) and Sumati- CSRC, } \\
\text { Gangavathi sona-05-01 }\end{array}$ \\
\hline Wheat & KRL 213, KRL 210, KRL 19 and KRL 1-4 \\
\hline Indian Mustard & CS 56, CS 54 and CS 52 \\
\hline Chick pea (gram) & Karnal Chana 1 \\
\hline Dhaincha (sesbania) & CSD 137 and CSD-123 \\
\hline
\end{tabular}

The other management technologies are,

1. Selection of tolerant varieties

2. Use of organic matter

3. Use of mulch

4. Foliar application of fertilizers

5. Fertilizer management

6. Integrated nutrient management

7. Phytoremediation

8. Green manures \& green leaf manure

9. Strip cropping (Manjunath, 2016, Naik, 2014 and Quadir, 2005)

\section{Selection of tolerant varieties}

\section{Avoidance of summer fallow}

Most of the coastal areas suffer from excess water in monsoon season with attendant problem of prolonged deep water submergence having adverse effect on crop growth. Whereas in winter and summer months, the capillary rise of the saline ground water impel the farmers to take only one rice crop in a year during the monsoon season. Introduction of second rice crop during the fallow periods, if good quality water for irrigation is available, can reduce the salinity level and increase the cropping intensity.

The high salinity is due to the high evaporation rate from soil during winter and summer months, if ground water is at shallow depth and rich in salt content. In coastal areas, the availability of good quality irrigation water is one of the major problems. However, if sufficient irrigation water of good quality is not available, a crop like chilli, barley, linseed, sugar beet can be grown whose crop canopy will reduce evaporation and thus there will be reduction in soil salinity. 


\section{Application of soil amendments}

Field experiments conducted at Coastal Saline Research Centre, Tamil Nadu Agricultural University, Ramanathapuram, Tamil Nadu revealed that application of agro-industrial wastes significantly improves oil organic carbon, $\mathrm{pH}, \mathrm{EC}$ and soil bacteria, fungus and actinomycetes population and enhanced the soil fertility status (macro and micro nutrients) and improved the crop productivity of finger millet. Application of press mud @ 1 2.5 tha $^{-1}$ recorded better growth and yield of fingermillet followed by composted coirpith @ $12.5 \mathrm{t} \mathrm{ha}^{-1}$ (Rangaraj et al., 2007). Application of lime and alkaline fly ash in proper combination to the coastal acid sulphate soils is effective for amelioration to some extent. Rice husk biochar could be used as a substitute for liming materials to improve the quality of acid sulphate soils. Increase in the $\mathrm{pH}$ of acid sulphate soil due to application of rice husk biochar is well documented. Amending coastal sandy soils with polyacrylamide @ 100-120 mg kg${ }^{-1}$ is useful for increasing the aggregation of soil, which in turn increases the water holding capacity of coastal sandy soil. This plays important role in highly permeable coastal sandy soils during dry summer months.

Addition of organic material either in the form of FYM, compost or green manure reduces the adverse effects of salinity on rice crop. Dhaincha (Sesbania cannabina), Shevari (Sesbania aegyptica) and leaves of bhend (Thespesia populanea) are found to be useful in increasing the yield of rice crop (Kadrekar et al., 1981). Linear response was observed with increasing doses of FYM upto $15 \mathrm{t} / \mathrm{ha}$ along with recommended dose of fertilizers (Chavan et al., 1990).

Mulching appears ultimately as the most efficient method in reclaiming these coastal saline soils (Aidara, 2017). Beye (1973) applied the mulching method to reclaim saline acid soil in the coastal area of southwestern Senegal and obtained up to 50\% reduction of salinity in the topsoil (around $30 \mathrm{~cm}$ ) after four years despite low rainfall during the trial period. But the lack of soil characterization makes these results really transient, limiting their large-scale application. Accordingly, Grigg et al., (2006) suggested further research in order to ascertain the long-time efficiency of the mulching technique.

\section{Growing of suitable crops}

In coastal areas, rice is the most preferable crop which is highly salt tolerant and can be grown under submerged condition. Rice cultivation promotes the leaching of salts from coastal saline soils. Adoption of rice crop in acid sulphate soils of coastal areas increases the $\mathrm{pH}$ of soil and thus reduces the iron and aluminium toxicity. Selection of suitable rice variety depending upon the salinity level and depth of water regime is highly appreciable. A large number of promising rice varieties have been developed/identified by Central Soil Salinity Research Institute, Karnal, Haryana and its regional research station at Canning, West Bengal for various waterlogging and salinity levels in kharif season. Other than rice, chilli, guava and sapota have been identified as salt tolerant vegetable and fruit crops for coastal saline soils. Growing of cashew in the coastal belt with proper irrigation and management practices may be beneficial.

\section{Nutrient management}

Most of the coastal soils are deficient in nitrogen due to heavy loss through volatilization, leaching and run-off. Phosphorus deficiency is also a common phenomenon in coastal acid sulphate or acid saline soils. Use of nitrogenous fertilizers is very much essential to obtain higher yield of 
crop in coastal saline soils. Application of rock phosphate as phosphorus source is highly beneficial for coastal acid saline soils. Long term fertilizer experiment showed significant response of rice crop due to application of nitrogenous fertilizers on coastal saline soils under rice-fallow cropping system. Integrated use of chemical fertilizers and farmyard manure (FYM) @ $15 \mathrm{t} \mathrm{ha}^{-1}$ is also a recommended practice for better use of fertilizer nutrients in coastal soils.

For effective utilization of land resources and betterment of livelihood of the local people in coastal areas, paddy-cum-fish culture can be adopted in lowland areas of coastal regions without much affecting the productivity of the soils. This may facilitate additional income generation to the farmers struggling for survival in the coastal regions and also uplift their socio-economic condition (Prasenjit Ray et al., 2014).

\section{Phytoremediation}

Phytoremediation, also known as vegetative bioremediation, is an approach for saline soil remediation through the cultivation of saltaccumulating or salt-tolerant plants and is perceived as a sustainable and cost-effective technique (Qadir and Oster, 2004; Jesuset al., 2015; Jing et al., 2019). The successful growth of salt-tolerant plants in salt-affected areas (Imadi et al., 2016) and the various remediation mechanisms employed by plants (Munns and Gilliham, 2015) have been reported in previous studies. Basically, the two main mechanisms involved are based on either the exclusion of salt by the roots or the control of salt concentration and distribution (Haninet al., 2016).

The plant species used for phytoremediation are mainly halophyte, hyperaccumulator, salttolerant, or transgenic plants. Tamarix chinensis has been reported to successfully reduce the salt concentration in saline soils and increase the abundance of soil nutrients (Cao et al., 2014; Zhang et al., 2016). Lycium chinense is also classified as a halophyte (Zhao et al., 2002) and can grow in highly saline soil (Yuan et al., 2015). Gossypium hirsutum, commonly known as upland cotton, is classified as a salt-tolerant plant, although the levels of salt tolerance differ among cultivars (QadirM and ShamsM. 1997; Gossett et al., 1994).

Although using these plants for the purpose of phytoremediation in coastal saline soils has been reported, a comprehensive comparison of remediation efficacies and its underlying mechanisms across plant species, particularly in long-term treatments, has not been performed.

\section{References}

Aidara C. A. Lamine FALL. 2017. Sustainable management of coastal saline soils in the Saloum river Basin, Senegal. Int. J. Biol. Chem. Sci. 11(4): 1903-1919.

Bandyopadhyay, A. K., and Bandyopadhyay, B.K.1984. Fertil News, 29(8): 18-22

Bandyopadhyay and Sarkar D. 1987. Occurrence of acid saline soils in coastal area in Sunderban area of West Bengal. Journal of Indian. Society of Soil Science 35: 542-4.

Bandyopadhyay AK. 1994. Management of land and water resources in the eastern coastal region of India. Diamond Jubilee National Seminar of ISSS

Beye G. 1973. Une methode simple de dessalement des sols de tanne de Casamance: le paillage. Agro Trop., 28(5): 537-549.

Biswas, C.R. et al., 1990. J. Indian Soc. Coastal Agric. Res., 8 (1):37- 41.

Chavan A.S., Mehta V.B., Chavan K.N. and Joshi R.G. 1990. Salt affected soils of south west coast of India and their effective utilization. Paper presented in 14th ICSS held in August 1990 at Kyoto, Japan. 
Cao D, Shi F, Koike T, Lu Z, Sun J. 2014. Halophyte plant communities affecting enzyme activity and microbes in saline soils of the Yellow River Delta in China. Clean Soil Air Water 42:1433-1440. doi:10.1002/clen.201300007.

Gossett DR, Millhollon EP, Lucas MC. 1994. Antioxidant response to $\mathrm{NaCl}$ stress in salt-tolerant and salt-sensitive cultivars of cotton. Crop Sci. 34: 706-714. doi:10.2135/cropsci1994.0011183X00340 0030020x.

Grigg AH, Sheridan GJ, Pearce AB, Mulligan DR. 2006. The effect of organic mulch amendments on the physical and chemical properties and revegetation success of a saline-sodic minespoil from central Queensland, Australia. Australian Journal of Soil Research, 44: 97-105.

Gupta, R.K. and Abrol, I.P. 1990. Salt-affected soils; their reclamation and management for crop production. In "Advances in Soil Science" (R. Lal, and B.A. Stewart, eds.), pp. 223-288. Springer, New York

Hanin M, Ebel C, Ngom M, Laplaze L, Masmoudi K. 2016. New insights on plant salt tolerance mechanisms and their potential use for breeding. Front Plant Sci 7:1787. doi:10.3389/fpls.2016.01787.

Imadi SR, Shah SW, Kazi AG, Azooz MM, Ahmad P. 2016. Chapter 18 phytoremediation of saline soils for sustainable agricultural productivity, $\mathrm{p}$ 455-468. In Ahmad P (ed), Plant metal interaction. Elsevier, Philadelphia, PA.

Jesus JM, Danko AS, Fiuza A, Borges MT. 2015. Phytoremediation of salt-affected soils: a review of processes, applicability, and the impact of climate change. Environ Sci Pollut Res Int 22:6511-6525.

Jing C, Xu Z, Zou P, Tang Q, Li Y, You X, Zhang C. 2019. Coastal halophytes alter properties and microbial community structure of the saline soils in the Yellow River Delta, China. Appl Soil Ecol 134:17. doi:10.1016/j.apsoil.2018.10.009.

Kadrekar S.B., Chavan A.S., Chavan K.N., Sahu R.K., Ingle B.V. and Joshi R.G. 1981.Summary of Research on coastal saline soils of Maharashtra. A brochure (Konkan Krishi Vidyapeeth, Dapoli).

Mahajan, G. R., B.L.Manjunath, A.M. Latare, Ruenna D'Souza, Shashi Vishwakarma, N.P. Singh. 2015. Fertility Status of the Unique Coastal Acid Saline Soils of Goa. Journal of the Indian Society of Soil Science, 63(2): 232-237

Mahendran, S. (2007). Technology development for saline water irrigation to increase the crop production in the coastal saline soils of Ramanathapuram district. CSRC. TNAU.

Manjunath, B.L., Gopal, R., Maharajan, R., Ramesh, R., and Singh, N. P. 2016. Effect of improved nutrient management on grain yield of rice and soil health under organic management. Indian J. Agron., 61 (1):25-32.

Munns R, Gilliham M. 2015. Salinity tolerance of crops - what is the cost? New Phytol. 208:668-673. doi:10.1111/nph.13519.

Naik, V.R., Patel, P.B., and Patel, B.K. 2014. Study on effect of different organics on yield and quality of organically grown onion. The Bioscan. 9 (4): 1499-1503.

Oster, J.D. and Jaywardane,N.S. 1998. Agriculturalman- agement of sodic soils. In Sodic Soil: Distributionm Management and Environmental Consequences (M.E. Sumner and R. Naidu, Eds.). Oxford University Press, NewYork,pp.126-147.

Ponnamperuma, F.N. (1972). Ad. Agron.,24: 29-92.

Prasenjit Ray, B.L. Meena, Chaitanya Prasad Nath. 2014. Management of Coastal Soils for Improving Soil Quality and Productivity Popular Kheti, 2(1): 95-99.

QadirM and ShamsM. 1997.Some agronomic and physiological aspects of salt tolerance in cotton (Gossypium hirsutumL.). J Agron Crop Sci.179:101106.doi:10.1111/j.1439037X.1997.tb00504.x.

Qadir M, and Oster JD. 2004. Crop and irrigation management strategies for saline-sodic soils and waters aimed at environmentally sustainable agriculture. Sci Total Environ 323:1 19. 
doi:10.1016/j.scitotenv.2003.10.012.

Quadir, M., Noble, A.D., and Oster. 2005. Driving force for sodium removal during phytoremediation of calcareous sodic and saline sodic soil. Soil Use and Management. 21:173-180.

Rajput, S.G. and Polara, K.B. 2012. Fertility status of cultivated soils in coastal Bhavnagar district of Saurashtra region of Gujarat. Journal of the Indian Society of Soil Science 60, 317-320.

Rangaraj, T., Somasundaram, E., Mohamed Amanullah, M., Thirumurugan, V., Ramesh, S. and Ravi, S. 2007. Effect of agro-industrial wastes on soil properties and yield of irrigated finger millet (Eleusine coracana L. Gaertn) in coastal soil. Research Journal of Agriculture and Biological Sciences, 3(3): 153-156.

Reitz, D.N. and Haynes, R.J. 2003.Effect of irrigation- induced salinity and sodicity on soil microbial activity. Soil Biology and Biochemistry, 35:845-854.

Sardinha, M., Muller, T., Schmeisky, H. and Joergensen, R.G. 2003.Microbial performance in soil along a salinity gradient under acidic conditions. Applied Soil Ecology, 23: 237-244.

Sen, H.S. and Maji, B.. (1994). Status of research and management of coastal saline soils for increasing crop productivity and future scope for improvement. 64: 211-218.

Vijayakumar, M., Lakshmi, G.V. and Madhuvani, P. 2013. Appraisal of soil fertility status in salt-affected soils of
Ongole division, Prakasam district, Andhra Pradesh. Journal of the Indian Society of Soil Science 61:333-340.

Velayutham M, Sarkar D, Reddy RS, Natarajan A, Shiva Prasad CR, Challa O, Harindranath CS, Shyamapura RL, Sharma JP and Bhattacharya T. 1998. Soil resources and their potentials in coastal areas of India. Paper presented in frontiers of research and its application in coastal agriculture: 5th National Seminar of Indian Society of Coastal Agricultural Research.

Velayutham, M., Sarkar, D., Reddy, R.S., Natarajan, A., ShivaPrasad, C.R., Challa, O., Harindranath, C.S., Shyampura, R.L., Sharma, J.P. and Bhattacharya, T. 1999.Soilresources and their potentialities in coastal area of India. J. Indian Soc. Coastal Agric. Res., 17(1\&2): 29-4

Yuan G, Yu Q, Feng X, Xie Z, Liu X. 2015. Effects of partial defoliation on the growth, ion relations and photosynthesis of Lycium chinense Mill, under salt stress. Arch Biol Sci (Beogr) 67:1185-1194. doi:10.2298/ABS150211094G.

Zhang L, Song R, Wu X. 2008. Salt tolerance capability of Tamarix chinensis and the effects on the improvement of coastal saline soil. J Anhui Agric Sci 36: 54245426.

Zhao K, Fan H, Ungar IA. 2002. Survey of halophyte species in China. Plant Sci 163: 491-498. doi: 10.1016/S01689452(02)00160-7.

\section{How to cite this article:}

Arulmathi, C. and Porkodi, G. 2020. Characteristics of Coastal Saline Soil and their Management: A Review. Int.J.Curr.Microbiol.App.Sci. 9(10): 1726-1734. doi: https://doi.org/10.20546/ijcmas.2020.910.209 